\title{
HOW CAN WE HELP TO RAISE AN ENVIRONMENTAL AWARENESS IN THE SOUTH AFRICAN CONTEXT?
}

\author{
Ernst M Conradie \\ Department of Religion and Theology \\ University of the Western Cape
}

\begin{abstract}
This article reflects on the question formulated in the title, i.e. "How can we help to raise an environmental awareness in the South African context?" It analyses some of the assumptions underlying this question. It argues that environmental problems cannot be addressed only through information and education, through science and technology or through governments and the laws that they promulgate. Christians can contribute to an environmental ethos through helping to articulate a moral vision for society, by practicing ecological virtues and by engaging in moral decision making in every sphere of public life.
\end{abstract}

\section{Introduction}

We have by now witnessed three decades of environmental conscientising, outcries, statistics, analyses, programmes and movements. The media regularly feed us with stories about environmental disasters. We are confronted with daunting statistics about deforestation, the extinction of species, global warming, population growth and insurmountable waste dumps. Despite this huge effort and although the global community has made some progress on issues such as acid rain and ozone depletion, we have not been able to turn the tide of consumption, pollution, increasing population, deforestation, over-fishing and the exploitation of non-renewable resources.

At the same time, we have to acknowledge that the earth's well-being has not been a major concern of churches in South Africa. Sadly, this is understandable. The social agenda of the church in South Africa is already filled to the brim. For many years we have been preoccupied with the struggle for political liberation, democracy, social reconciliation and economic reconstruction. In addition to the classic responsibilities of attending to those who are poor, sick, hungry, homeless, abused, elderly, orphaned, illiterate, deaf, blind, or handicapped, the church in South Africa has to address numerous social problems such as poverty, unemployment, violence against women and children, education, housing, health services, corruption and crime, racial discrimination and now, most pressingly, the HIV/AIDS pandemic. As the stark and daunting realities of HIV/AIDS are dawning on us, we may well feel overwhelmed by such a formidable social agenda. Moreover, many local churches are completely entangled in the weekly struggle of maintaining the institution, its activities and its financial health.

The question raised in the title of this contribution is born from these observations. Indeed, how can we as Christians help to raise an environmental awareness in the South African context? This question requires a complex answer. Perhaps the question can best be addressed by analysing the assumptions underlying the various aspects of the question itself. 


\section{How should the word environment be defined?}

There is a need to reach some clarity on the use of terms such as the "environment", "nature", "ecology", the earth and "creation". The meaning of all these terms has become contested.

Although Christians often use the word "creation" to refer to the earth or the cosmos, this term clearly has a religious emphasis. It articulates the Christian faith in God as Creator. Although Christians live within the created order and are called to nurture it, creation itself is the work of the Creator, not of human beings. The word "ecology" should preferably be used in the more limited sense of referring to the scientific disciplines that study the functioning of various ecosystems, although the adjective "ecological" may also be used to describe the health of ecosystems. The word "nature" is notoriously complex as is evident in the famous debates on "the nature of nature." In this contribution I will focus on the notion of the "environment" instead of "nature" in order to indicate that an ecological theology is not only concerned with nature, in the sense of "nature out there". Especially three initiatives to develop an integrated notion of the environment may be noted here:

a) The "environment" may be understood in terms of a number of concentric circles, starting in the centre with our own bodies as an integral part of the earth's ecosystems, the environment in which we live (our homes), the environment in which we work, the environment as "nature out there" and global environmental concerns such as nuclear threats, global warming, ozone depletion, deforestation and the loss of biodiversity. ${ }^{1}$

There is an urgent need in South Africa to counter the popular perception that environmental issues boil down to nature conservation. In this way a concern for the environment is reduced to "nature out there", to the preservation of endangered species in game reserves, to wildlife issues, to an appreciation of the unspoilt beauty of some of South Africa's countryside. It is crucial to bring the environment closer to home - to where people live and work. Endangered species have to be protected in wilderness areas precisely as a result of urban and industrial "developments" using up all the other available land. Nature conservation in wilderness areas is in this sense only an emergency measure that leaves the primary problem untouched. This emphasises the need to locate environmental concerns within the mainstream of economic activities (industry, commerce, agriculture, fisheries, forestry, mining, services, etc). The environmental impact of each of these sectors of the South African economy needs to be assessed.

Moreover, environmental concerns should be related to people's living conditions. Economic activities take place precisely because consumer goods and services are in demand as a result of the consumerist lifestyles and cultural patterns of ordinary people. $^{2}$ It is necessary to reflect on the environmental impact of the food we eat, the resources we consume, the various forms of energy that we use, the transport that we need, the consumer goods that we require, the cleaning products that we use, the waste that we generate, etc. The full life cycle of each of these aspects should be investigated (in terms of production, distribution, consumption and waste management).

1. See Conradie \& Field (2000:12f) for an assessment of various environmental problems (with specific reference to the South African context), following this model of concentric circles.

2. For a critique of a consumerist society from an environmental perspective, see, e.g. Conradie (2002), Gunton (1993), McFague (2001:81-97), Schut (1999), Swimme (1996). 
The environment is even closer to us than that. Our own bodies form part of the environment in which we live. We are living in the earth and form part of the earth. Nature is part of our daily lives. We experience it in the water we drink, the air we breathe, the food we eat and the clothes we wear. That environmental problems are far closer to home than we could ever have imagined, is vividly expressed by Jürgen Moltmann's comment that we carry the symptoms of the ecological crisis in our own bodies $^{3}$

b) In recent ecumenical literature the Greek metaphor of "oikos" (house) has been widely used to develop an integrated understanding of the social agenda of the church in terms of the health of the whole household of God. The etymological link between economy and ecology, both deriving from oikos, is often emphasised. The discipline of economics reflects on appropriate laws or rules (nomoi) for the household, on the art of administering the global household. The science of ecology gathers knowledge on the "logic" (logos) of the same household, that is, the incredibly intricate ways in which ecosystems interact to ensure the functioning of the biosphere. The term "eco-justice" captures the need for a comprehensive sense of justice that can respond to both economic injustice and ecological degradation. The word oikos is also the etymological root of oikoumene, the whole inhabited world. "Ecumenics" therefore means treating the inhabitants of the household as a single family, human and nonhuman together, and fostering the unity of that family. ${ }^{4}$ Moreover, as Larry Rasmussen observes, if English had adopted the Greek word for steward (oikonomos), we would immediately recognise the steward as the trustee, the caretaker of creation imaged as oikos. ${ }^{5}$ Finally, in his stimulating study, God's Spirit: Transforming a world in crisis, Geiko MüllerFahrenholz has developed these insights through the notion of "ecodomy", derived from the Greek word oikodomé. Ecodomy is the art of inhabiting instead of dominating the earth, our house. Müller-Fahrenholz explains:

In its literal sense this term refers to the building of the house, but its meaning can be extended to any constructive process. So the apostle Paul uses the word for the building up of Christian communities. He calls his apostolic mission a service to the oikodomé of Christ (2 Cor. 13:10). He reminds members of Christian communities that they should behave towards each other in the spirit of oikodomé (Rom. 14:19). They are called to use their specific gifts and talents (charisms) for the oikodomé of the Body of Christ (Eph. 2:21), just as they are reinforced and strengthened by the pneumatic energy of this body. ${ }^{6}$

Müller-Fahrenholz subsequently calls on Christian congregations to become ecodomical centres and to form ecodomical networks and covenants that can respond to the demands of the contemporary world. The calling of the church is to become partners in God's ecodomy.

From these observations there has emerged what may now be called an "oikos"theology. ${ }^{7}$ The root metaphor for this theology is the whole household of God. It is primarily concerned with the health of all forms of life in this one household of God. It is thus able to integrate a variety of concerns, including the following:

3. Moltmann (1989:75).

4. Raiser (1997:49).

5. Rasmussen (1994:118).

6. Müller-Fahrenholz (1995:109).

7. See, especially Cobb (1992:55f), Müller-Fahrenholz (1995), Rasmussen (1994, 1996), Raiser (1997:49-51). 
- the integrity of the biophysical foundations of this house (the earth's biosphere),

- the economic management of the household's affairs,

- the need for peace and reconciliation amidst ethnic, religious and domestic violence within this single household,

- a concern for issues of health and education,

- the place of women and children within this household, and

- an ecumenical sense of the unity not only of the church, but also of the human community as a whole and of all of God's creation, the whole inhabited world (oikoumene).

c) The term "Earth" is sometimes used instead of "the environment." Perhaps the term "environment" lacks the concreteness of a black rhino, a yellow wood tree, a dolphin, a fish eagle or Table mountain. Furthermore, the word environment suggests something that we live in, but which is apart from us, rather than the home we inhabit and of which we form an integral part. This does not help to prevent a harmful alienation between humans and the rest of nature. The term environment also fails to capture the blooming, buzzing confusion of creatures in dynamic interaction with one another that is so typical of the earth community. Many therefore simply prefer to speak of the earth, or often earth (without the article) or Earth (with a capital). The evocative notion of "earth" is suggestive of the earth community that we as humans form part of. This sense of Earth as a single community of life is often inspired by the pictures of the "blue planet" taken by astronauts from outer space.

These approaches towards an integrated view of the environment also indicate the need for a multi-disciplinary approach to address environmental concerns. The environment has become a concern in virtually every conceivable academic discipline, including astro-physics, chemistry, geology, geography, biochemistry, evolutionary biology, botany, zoology, medicine, agriculture, fishing, forestry, nature conservation, ecology, engineering, economics, politics, management, law, education, language, the social sciences, the fine arts, philosophy, ethics and theology. It has become obvious that such a multi-disciplinary approach is required to understand the logic of our planetary household (ecology).

\section{What specific challenges does the South African context present?}

Since the early 1970's numerous studies have accumulated evidence of regional and global environmental disasters. This has stimulated the emergence of an environmental awareness, especially since the publication of the famous "Limits to growth" report. The earlier emphasis was on a variety of environmental problems, including the following:

- the world's increasing population,

- the scarcity of resources and energy supplies (this was particularly important in the light of the oil crisis in the 1970's),

- the potential danger of nuclear war (e.g. during the years of the "cold war"),

- the protection of endangered plant and animal species,

- several issues around animal experimentation, animal farming and other forms of cruelty against animals,

8. Raiser (1997:49). 
- the problem of soil erosion,

- the problem of (industrial) pollution in its more visual forms,

- the management of urban waste.

These environmental problems intensified during the following decades. Not only have the number and extent of these problems increased, but also their "quality", that is their potential danger for the future of life on earth. These environmental hazards include the following:

- the looming possibility of global warming,

- the hazard of ozone depletion,

- the problem of acid rain and air pollution,

- the disposal of nuclear waste,

- the management of highly toxic forms of waste,

- the virtual destruction of the rainforests and other ecosystems,

- the rapid loss of biodiversity,

- the salination of soil,

- the virtual collapse of some fishing industries due to persistent over-fishing.

From the mounting evidence on environmental degradation it has become clear that the very building blocks of life itself (air, water, soil, energy) are threatened as a result of environmental destruction. It has become increasingly clear that, "The future ain't what it used to be." Or: "If current trends continue, we will not!" These environmental concerns cannot be discussed here in any detail. There are numerous technical and more popular publications that may be consulted on aspects of the environmental crisis. Likewise, there are numerous publications that discuss environmental concerns in sub-Saharan Africa and in South Africa, ${ }^{9}$ also with specific reference to the environmental impact of apartheid. ${ }^{10}$

For the sake of an environmental awareness amongst all South Africans, it is crucial to grasp that many of these environmental problems are intertwined with the problems that the poor and marginalised in South Africa experience in their everyday lives.

- In general, the poor and marginalised are driven to live in physical conditions that are of a bad environmental quality (and which are therefore "open" for occupation). The poorest often live (and work!) on urban waste dumps. Others accept employment in dreadful environmental conditions with grave risks to health (e.g. smoke, toxic gases, pesticides).

- In rural areas, the scarcity of clean drinking water and firewood are environmental problems at their very roots. Deportation under apartheid led to over-population and thus to overgrazing, soil erosion and exhaustion and a depletion of water supplies. Many resort to poaching and forms of deforestation as a survival strategy. This causes further environmental damage and increases poverty, leading to a vicious circle.

- In urban areas, people are often the victims of environmental degradation caused elsewhere, often by nearby industries. Townships were often precisely located on land that was not in demand. However, people living in previously disadvantages areas are also the cause of some environmental problems. In fact, most of the problems that

9. See, e.g. the popular books by Cock \& Koch (1991), Huntley, Siegfried, \& Hunter (1989), McDoanld (2002), Whyte (1995), Yeld (1997) and the major scholarly work by Fuggle \& Rabie (1992).

10. See, especially, Cock \& Koch (1991), Durning (1990), Ramphele \& McDowell (1991). 
people experience on a daily basis are environmental problems - even though these are usually not recognised as such. Look at the following examples:

- The health hazards caused by air pollution - either through nearby industries or through braziers, the burning of coal,

- the pollution of water supplies,

- informal settlements are characterised by a very high population density;

- Inadequate sanitation,

- a high incidence of contagious diseases,

- the visual ugliness of pollution, leading to a lack of basic human dignity,

- regular flooding or landslides,

- a lack of basic infrastructure,

- cutting of trees for firewood in the neighbourhood,

- the struggle for political control over ever-scarcer resources. ${ }^{11}$

Although environmental degradation affects all human beings, it does not do so equally. There is a growing recognition that the victims of environmental degradation are also the victims of socio-economic injustice. ${ }^{12}$ The worst victims of poisoning and pollution are the poor and marginalised. These include various groups of marginalized people on the economic periphery, e.g. indigenous peoples, environmental refugees, women, children, the poor, mine workers, factory workers and farm workers. Environmental injustices are indeed aggravated by practices such as exploitative economic policies, racial polarisation, gender discrimination and class inequities. It is not only human beings who are the victims of environmental degradation though. The victims include numerous animals, fish, birds, insects, plants, etc. Not only individual specimens, but also whole species are victimised as a result of environmental destruction.

These observations point to the inextricable link between environmental degradation and issues of justice. There can be no serious commitment to social and economic justice that does not include an ecological responsibility and vice versa. The well-being of human beings is inseparably linked with that of all life on earth. Environmental degradation is not a separate concern from poverty, deprivation and economic exploitation but often a manifestation thereof. The term "eco-justice" is sometimes used to capture the need for a comprehensive sense of justice that can respond to both economic injustice and ecological degradation. Dieter Hessel defines "eco-justice" in the following way:

A combination of ecology and social justice, "eco-justice" refers to the interlocking web of concern about the earth's carrying capacity, is ability to support the lives of its inhabitants and the human family's ability to live together in harmony. It highlights the interrelatedness of such pressing issues such as world hunger and world peace, the energy crisis and unemployment, appropriate technology and good work, biblical stewardship and feminist consciousness, radical justice and pluralistic community, lifestyle choices in response to poverty and pollution. ${ }^{13}$

11. See the excellent article by Lawson, "The ghetto and the greenbelt" in Cock \& Koch (1991:46-63), Samita's assessment of environmental challenges in Nairobi (2002) and, from a Latin-American perspective, Gudynas (1995). See also the discussion in Conradie \& Field (2000:18f).

12. For a more detailed discussion, see Conradie \& Field (2000:16f, 41f).

13. Hessel (1985:12). 
The Environmental Justice Networking Forum in South Africa (EJNF) has also adopted the struggle for environmental justice as its point of departure. The struggle for environmental justice seeks to challenge the abuse of power that results in the situation that poor people have to suffer the effects of environmental damage caused by the greed of others. ${ }^{14}$ In the National Environmental Management Act (107 of 1998), the South African government also emphasised the link between environmental protection and issues of social and economic justice. It should indeed be clear that environmental concerns can be addressed in the South African context only within the context of issues of justice.

\section{Is more than an environmental awareness not necessary?}

One may well argue that an appropriate environmental praxis is far more urgent than an environmental awareness. From a Marxist perspective one may add that the key to environmental praxis is not "awareness" but material processes that will stimulate or in the end force us to adopt more ecological practices. Indeed, one has to take the danger of false consciousness into account, especially with reference to the way in which environmental degradation is exacerbated by the pervasive ideologies of neo-colonialism, sexism, racism, classism and, in particular, anthropocentrism. Moreover, the most appropriate way of raising an environmental awareness may well be to learn from and to follow concrete examples and models of environmental praxis.

Any adequate response to environmental degradation will have to be at the level of praxis and not only at the level of theory, ideas or awareness. The problem is that even those who have become thoroughly conscientised often find it difficult to translate an awareness of ecological concerns into appropriate praxis. All too often environmental problems seem so daunting and overwhelming that it is difficult to know where to start. For the urban middle class it is especially difficult to adopt a lifestyle that is not harmful to the environment. One may take some modest steps such as recycling, reducing the use of electricity, water, transport, chemicals, re-using resources, etc. Such steps would be highly appropriate to challenge the consumerist habits of the middle class. However, a guilty conscience and a $10 \%$ reduction in the use of resources would not be enough. As Patricia Mische comments:

... most people now know that we have serious ecological problems. But there is a lingering gap between knowing that we face serious ecological problems and acting on this knowledge in our personal, political and social choices. While more people have taken some modest steps, such as recycling, changes in people's worldviews, attitudes and behaviour have not been commensurate to the gravity and global scale of the problems. Moreover, when in conflict, economic concerns and desires usually trump environmental ones. ${ }^{15}$

Despite these caveats, the choice of the word "awareness" indicates that the extent of environmental degradation is not yet sufficiently recognised. As the German ethicist HansEduard Tödt has also argued, the recognition of a problem forms a prerequisite for responsible action. It is sometimes a matter of seeing the problem. Some of us see, for example, that the present use of fossil fuels (for electricity, cars, aeroplanes) is damaging to the environment and that it is simply not sustainable for another 50-100 years while others do not recognise the problem at all. Of course, as Tödt also argues, recognising a problem is not enough. It is also important to accept the problem, to consider available options, to

14. Information brochure of the Environmental Justice Networking Forum.

15. Mische (2000:592). 
evaluate such options in terms of social values, to take responsibility for a course of action and to evaluate this action afterwards in conversation with other role players.

\section{Why raising an environmental awareness is imperative ...}

We have reached a point where our senses have already been numbed by the evidence regarding environmental destruction. In the popular consciousness the sense of a looming environmental crisis lurks beneath the surface as a silent but pervasive fear for the longterm future of life on this planet. There is a deep-seated cognisance that environmental problems will not go away. We know intuitively that many of our present practices will not be sustainable in the years ahead. We now know that human well-being is dependent on the well-being of the land. We need to care for the land so that the land can care for us.

Nevertheless, an environmental awareness cannot be taken for granted; it must be fostered, nurtured, developed. This is particularly important in the light of various conflicting perceptions on what an environmental awareness entails. ${ }^{16}$ The "environment" means different things to different people, especially in the South African context. Some focus on "nature out there", i.e. the relatively unspoilt beauty of the countryside. Others are anxious about global environmental catastrophes. Some are primarily concerned with a healthy working environment for employees. Others are worried about limited resources or may be involved in a daily struggle to sustain themselves. Some focus on the ongoing task of managing natural resources, e.g. in businesses, on farms or in local government services. Others regard environmental disasters simply as news items or as an interesting point of social conversation.

These different perceptions on the environment are exacerbated by various forms of resistance against environmental agendas. The nature conservation policies of the apartheid era provoked the suspicion that conservation boils down to the establishment of game reserves for a privileged few, often at the expense of the dislocation of local people. Many urban blacks view issues of nature conservation as a concern of the white middle class, ${ }^{17}$ the hobby of an affluent, leisured minority who would like to preserve the environment for purely aesthetic reasons and who seem more concerned about wildlife than about the welfare of other human beings. The primary concern of others is the day-to-day struggle of surviving in overcrowded, squalid, unhealthy conditions. Others fear that attention to environmental concerns may divert scarce human and financial resources from the more pressing issues of poverty, HIV/AIDS, hunger and employment. ${ }^{18}$ Indeed, finding employment now may seem far more urgent than the long-term environmental impact of mining,

16. See Conradie \& Field (2000:8).

17. In 1991 Frank Chikane (quoted in Niles 1992:36) expressed a similar skepticism regarding the priority of the environment on the social agenda of the church:

To most of us who come from countries which are ravaged by senseless wars, characterized by gross violations of human rights and by massive poverty and unemployment, the introduction of the item of the integrity of creation on our agenda seemed like a conspiracy by those who benefit out of our poverty and oppression, to divert and diversify our struggle for justice in our situations. It seemed like some people wanted to keep us busy with seeming abstract concerns about the misuse of biotechnology rather than the real issues of land dispossession and racism, sexism, economic exploitation (classism), political oppresssion, and denial of the right of religious freedom and the use of religion as an instrument of oppression.

18. Leonardo Boff (1995:12) quotes (but then also refutes) the following argument:

Ecology is a luxury of the rich. It is a product of the northern hemisphere. These people have despoiled nature in their own countries and have robbed the colonized peoples of the entire world, and after all that are now claiming a safe ambience and ecological reserve for the preservation of a species in the process of decline. 
manufacturing, business, farming, forestry or fishing. Yet others may suggest that a concern for the environment may hamper technological progress, entrepreneurship, and a better standard of living for all.

For many South Africans environmental concerns remain fairly remote and distant. Environmental concerns seem all too long term, almost imperceptible and unrelated to our daily lives and aspirations. They seem all too serious and gloomy and stand in the way of an enjoyment of life and its many pleasures. Some regard environmental problems as less serious and are confident that technological solutions will in due time become available to resolve existing environmental concerns. Others argue that environmental problems may indeed be serious, but that all of us are caught up the web of modern society. "What can we do?" they ask themselves, "We simply need cars, electricity, water, oil, refrigerators, cleaning products, batteries, etc., etc." Yet others are annoyed by the campaigns of radical environmental activists. They do not want to jump on any green "bandwagon".

Within the context of Christian communities a different form of resistance against environmental agendas may be encountered. Many Christians will question whether the environment should really be regarded as a priority on the social agenda of the church. Should the church not be engaged in far more urgent issues such as poverty, unemployment, education, housing, health services, crime and now, most pressingly, the HIV/AIDS pandemic? Some Christians feel that the church should primarily be concerned with the message of salvation: that Jesus Christ came to save human beings from sin and to reconcile us with God. The vertical relationship with God is more important than a horizontal concern for the environment. From a different angle other Christians dismiss environmentalism as being "New Age". They feel uncomfortable and threatened and fear that working with others towards a "green" agenda may compromise their faith. In some extreme forms of Christianity, people even argue that one should oppose efforts to ameliorate poverty, prevent war, or clean up ecological damage, for this is to oppose God's will and delay the final judgement. ${ }^{19}$

In addition to these conflicting perceptions of the environment and the various forms of resistance against environmental agendas, the widespread human alienation from nature, especially in urbanised, industrial societies should not be underestimated. Although most South Africans are convinced that they do appreciate nature, that they love the land deeply, this alienation of human beings from the land has become widespread. We have for too long thought of ourselves as somehow separate from nature. Larry Rasmussen refers to the "apartheid habit" of distinguishing between humanity and non-human nature, leaving the impression that we are an ecologically segregated species, that we are somehow separate, hence "apart" from the ecosystems in which we live. ${ }^{20}$ Rasmussen adds that the same "apartheid habit" is also manifested in the "great divorce" of nature from (human) history. Human beings and the history of humanity should be regarded as a mere episode in the larger history of the cosmos itself and of life in (not on) this planet. ${ }^{21} \mathrm{~A}$ similar assessment of the alienation of human beings from nature is evident in the striking metaphor of "autism" that Thomas Berry uses:

In relation to the earth, we have been autistic for centuries. Only now have we begun to listen with some attention and with a willingness to respond to the earth's demands that we cease our industrial assault, that we abandon our inner rage against the conditions of

\footnotetext{
19. Ruether (1992:84).

20. See Rasmussen (1996:75).

21. Rasmussen (1996:75-89).
} 
our earthly existence, that we renew our human participation in the grand liturgy of the universe. $^{22}$

Ernst Schumacher makes a similar comment:

Modern humanity does not experience itself as a part of nature but as an outside force destined to dominate and conquer it. Humans even talk of a battle with nature, forgetting that, if they won the battle, they would find themselves on the losing side. ${ }^{23}$

Sallie McFague comments on the same tendency:

We have lost the sense of belonging in our world and to the God who creates, nurtures, and redeems this world and all its creatures, and we have lost the sense that we are part of a living, changing, dynamic cosmos that has its being in and through God. ${ }^{24}$

\section{Who are responsible for raising an environmental awareness?}

Christianity has often been blamed for providing religious support for environmental destruction. In a famous article entitled "The historical roots of our ecologic crisis," published in 1967, the American historian Lynn White argued that the Christian tradition itself bears a huge burden of guilt for the worldview that has led to the present ecological crisis. White argued that it is but a small step from the Christian notion of the dominion of man(!)kind over nature to the senseless exploitation of nature for human benefit. Compared to the emphasis on the sacredness of nature in most other religions, the Judeo-Christian doctrine of creation has led to a "disenchantment of nature." 25

White's article led to a heated debate and almost single-handedly sparked off the discussion of environmental issues in Christian theology. It is not necessary to revisit this debate here. ${ }^{26}$ The thought-provoking report entitled, Towards the greening of the church in South Africa (1991), by South African sociologist Jacklyn Cock may be noted though. In this report Cock investigated the environmental awareness amongst church leaders and in official church publications and resolutions on the environment. She concluded that there is a "blind spot" and a "deep silence" within the Christian church in South Africa on environmental issues. The reasons given (and defended!) by her informants (for the silence of the church on environmental issues) tend to confirm Lynn White's suspicions. These reasons include the following: a preoccupation with human salvation, the doctrine of divine transcendence, the emphasis of the Judaeo-Christian tradition on human domination over nature, the dismissal of environmental issues as "new age" and even the perception that the ecological crisis confirms the Biblical apocalyptic prophecies. By contrast, Cock's interviews with environmental activists reveal a striking absence of any religious affiliation! ${ }^{27}$

Cock argues, nevertheless, that Christian churches should take the lead in addressing environmental problems in South Africa. She mentions the following reasons in this regard: a) The church in South Africa has an organised space at the grassroots level to promote mass environmental awareness, b) it has the necessary leadership for moral transformation, and c) a holistic, ecological vision has deep roots in the Christian tradition. The church also has important resources in terms of staff, institutions, agencies, networks, buildings, infra-

22. Berry (1988:215)

23. Schumacher (1973)

24. McFague (1993:34).

25. See White (1967).

26. See my discussion of this debate (Conradie 2001:38f).

27. See Cock $(1991,1992)$. 
structure, etc. to address environmental challenges effectively. ${ }^{28}$ The church in South Africa is, together with environmental programmes in schools, indeed in a unique position to play an important role in this regard. The church can make a difference because local Christian communities enjoy trust from people at grassroots level - more than any political party, labour union or community organisation. Together, Christian churches indeed form the largest, most influential and most active organisation in the country.

Cock has subsequently called for a "rainbow alliance" in which nature conservationists (green), environmental organisations focusing on justice issues (the so called "brown" agenda), labour movements (red), and religious groups (purple) should work together to ensure that life can flourish on this blue planet. $^{29}$

There is, of course, little need for Christian churches to duplicate the work of other environmental organisations. Churches should, instead, support the work of these organisations as far as possible, establish the necessary channels and networks of communication and encourage its members to participate in the work of these organisations. While Christians may ultimately have a distinct ecological vision, they could share the "penultimate" goals of many other environmental organisations. Perhaps churches should take the initiative only if no other organisation is addressing a particular problem. This would continue the approach followed by many churches and mission organisations in the past. They established schools, hospitals, centres for the disabled and elderly people, and agricultural projects, whenever no one else was doing it properly. Many of these projects were eventually funded or taken over by the government. More recently, some churches have again taken some responsibility for schools in areas where the local government is struggling to manage these schools efficiently.

\section{How, then, can Christians help to raise an environmental awareness?}

In the introduction we noted that, despite three decades of environmental conscientising, outcries, statistics, analyses, programmes and movements, we have not been able to turn the tide of consumption, pollution, increasing population, deforestation and the exploitation of non-renewable resources. Why is this the case? The problem has clearly not been a lack of information or planning. It is a liberal fallacy that information and education forms the clue to moral action. The problem is, in Christian terms, related to the devastating impact of sin on society, not to a lack of information. Solving the environmental crisis will therefore demand much more than what science and new technologies may offer. It is less a problem of know-what or know-how than of know-why and know-wherefore. ${ }^{30}$ The crisis that we have to face is not primarily an ecological crisis but a cultural crisis. The problem lies not outside but inside ourselves, not in the ecosystem but in the human heart, in the collective psyche. What is required a fundamental change of orientation, in Christian terms a metanoia. In their series foreword to the edited volume on Christianity and ecology, Tucker and Grim articulates a similar concern:

It is becoming increasingly evident that abundant scientific knowledge of the crisis is available and numerous political and economic statements have been formulated. Yet we seem to lack the political, economic, and scientific leadership to make necessary changes. Moreover, what is still lacking is the religious commitment, moral imagi-

\footnotetext{
28. Cock (1994).

29. See Cock (1992:182).

30. Rasmussen (1996:74).
} 
nation, and ethical engagement to transform the environmental crisis from an issue on paper to one of effective policy, from rhetoric in print to realism in action. ${ }^{31}$

Patricia Mische adds the following:

Science and technology alone cannot resolve ecological threats. Nor can governments or the laws they promulgate ... sustaining the integrity of creation thus requires not only the external laws governments enact to deal with belligerent behavior, but also inner governance, laws internalised in our hearts and minds and the will to live by them. The need for inner governance is relevant not only to personal behavior, but also collective behavior through the economic, social and political systems we create and help maintain. Church praxis has special relevance for the development of inner governance and a culture of ecological responsibility. Religions carry the archetypes, symbols, meanings, values and moral codes around which people coalesce and define themselves, their sense of the sacred, and their relationships with each other and the natural world. ${ }^{32}$

How, then, can we raise an environmental awareness in the South African context? The problem seems to be one of a lack of moral vision, imagination, will and leadership. Since moral formation typically takes place within faith communities, this implies that it is, at its very core, a religious problem that we have to address. This also implies that Christian systematic theologians and ethicists have a very significant task in this regard. This is all the more important in the light of the world-denying tendencies that have all too often infiltrated the Christian tradition. In my view, there are especially three crucial areas where Christian piety has often inhibited an environmental ethos, spirituality and praxis, namely an escapist eschatology, a worldless notion of God's transcendence and a personalist reduction of the cosmic scope of salvation. ${ }^{33}$ Any ecological theology will remain shallow unless an adequate response to these three problems can be provided. Ecological theology has to be more than environmental ethics or a revisited theology of creation.

Doctrinal and ethical reflection will, of course, not be sufficient to raise an environmental awareness. In more practical terms, the "how?" question may be answered in various ways. Consider the following possibilities: ${ }^{34}$

- In Christian contexts a concern for the environment is very often expressed in the form of prophetic warnings (e.g. on the basis of an accumulation of ominous statistical evidence). ${ }^{35}$ At best, such prophetic contributions show how environmental destruction is linked to other forms of injustice - to the poor, to women and children, to indigenous peoples. Prophets may also want to call for obedience to God's commandments in order to care for the environment.

31. Tucker \& Grim (2000:xix).

32. Mische (2000:592-3).

33. See my attempt (Conradie 2000) to address these three issues from a point of departure in the notion of "hope for the earth".

34. See the analysis by Gustafson's (1994) of four varieties of moral discourse: i.e. prophetic, narrative, policy and ethical discourse.

35. See Santmire (1989) and Wadell (1994) on the inadequacy of frightening people with ominous environmental facts and figures. Wadell (1994:57) comments on the need for moral perception and moral vision: "These facts should frighten us, but fear is not enough. Fear should lead to a change of perception; it should engender a moral vision more adequate to justice not only for ourselves, but also for future generations and all members of the earth, human as well as nonhuman. We will not live differently unless we first see differently, acknowledging the relationships we have with the natural world ... ours is a time in which perception is critical to any kind of human future." 
- Environmental anxieties are often expressed in popular culture (and in religious sects) in the form of apocalyptic forebodings of an imminent environmental catastrophe. ${ }^{36}$ This is evident from numerous horror movies, cartoons, science fiction literature, or heavy metal rock music. These are full of images of cosmic horrors, featuring, for example, vengeful insects or rats or machines taking over the world, frequently in the aftermath of a nuclear catastrophe. In these latter-day apocalyptic portrayals of cosmic battles, the forces of the Light often save the day, but provide only temporary reprieve from the daily fears, cosmic despair and spiritual emptiness that pervade much of contemporary culture. ${ }^{37}$

- A concern for the environment is also articulated in the many stories of the victims of environmental destruction. These are stories told by mine, factory and farm workers, by those who live in the unhygienic conditions in squatter camps, those who live and work on rubbish dumps, by indigenous peoples who have become environmental refugees, by the plight of women and children in remote rural areas, etc.

- The sense of ugliness resulting from pollution and environmental destruction is acutely expressed in the aesthetic sensibilities of artists and poets, the "antennae of society". ${ }^{38}$

- These prophetic and narrative forms of moral discourse on the environment would remain shallow without the contributions of scientists from many disciplines who have to engage in the painstaking process of analysing and assessing the evidence of environmental degradation. This provides the raw material for further detailed analysis by economists, social scientists and ethicists. Such information is often used by the media and for education to persuade people with rational arguments why caring for the environment is in their own (long-term) interest.

- Environmental concerns are often expressed in the policy documents of international, regional, national, and local forms of government, in planning and management processes in the world of commerce and business and in declarations from civil society. Numerous Christians have contributed towards this task, especially within the context of the ecumenical movement.

The focus of most of these contributions is to concretise a vision of the good society towards policy making. In this regard the "middle axioms" formulated by ethicists may indeed be valuable. The formulation of such an ecological vision will be of little value, though, if these values are not embedded in Christian praxis. Since the publication of

36. See Santmire (1989:266f), also Keller (1993). Santmire (1989:265-6) expresses this almost apocalyptic sense of despair in quite graphic language:

The threat of mass catastrophe is now a commonplace of the popular mind. With the passing of each day, we are becoming more and more familiar with scenarios of global thermonuclear death and devastation, planetary ecological collapse, toxic pollution of our environment, vast blights of deforestation and soil erosion, constant economic crisis for the great majority of the earth's peoples, and rampant starvation in some regions of the world, all punctuated by the threats of nuclear accidents or terrorism and stories of increasingly capricious patterns of global weather. Hovering in our consciousness, as well, is the vague but dismal image of the end of cosmic history itself, ignomiously, eons from now, through some kind of universal "heat death." It is existentially thinkable today, perhaps as never before, that the final word being written across the pages of the whole human drama, and across the pages of the cosmos itself, is finis, termination, death with terror, torment, and excruciating moments of pain. These are apocalyptic times indeed. And the dark clouds of a future which is no future often flood backward, as it were, into the present, producing a deep-seated and widespread spiritual anomie.

37. See Santmire (1989:266).

38. There are numerous examples of this aesthetic environmental sensibility. See, especially, Rajendra (1987), Roberts \& Amidon (1991), Sharper \& Cunningham (1993). See also Baker-Fletcher's (1998) use of poetry, song and dance to elicit "wordings from the heart" from an ecowomanist perspective. 
Alisdair MacIntyre's influential work, After virtue, many Christian ethicists have emphasised the need to focus not only on such a vision for the good society but also on ecological virtues and vices. ${ }^{39}$ Environmental problems can only be addressed adequately by ecological people, people of good moral character, people who embody ecological virtues. In the literature on ecological virtues the need to retrieve virtues such as ascesis, frugality, gratitude, hospitality, humility, moderation and restraint (temperantia), is often discussed. There are numerous stories of people who have embodied these virtues in their own lives. These stories include examples of "ecological saints" epitomised by Francis of Assisi but also numerous contemporary figures who have devoted their lives to various environmental causes.

There remains, of course, a need for people with an appropriate ecological vision and who are embodying ecological virtues to engage in responsible and ecologically sensitive decision making and to clarify the relevant social priorities (values) in this regard. ${ }^{40}$ This is probably the most effective way of raising an environmental awareness, i.e. by adopting a sustainable lifestyle and by acting in an environmentally sensitive way. One can discern at least four levels at which Christians can respond to environmental issues at a practical level: ${ }^{41}$

a) Christians can make a difference where they live and where they work, wherever they exercise some influence in society.

b) Christians can co-operate with and support numerous existing environmental organisations.

c) Local Christian communities can become ecologically conscious communities.

d) There are numerous interesting stories, examples and case studies of environmental projects initiated by Christians. Perhaps this remains the most appropriate way of raising an environmental awareness, i.e. simply by practising what we preach.

There are indeed remarkable examples, also within a Christian context, of individuals and communities that have adopted an ecologically informed lifestyle and spirituality. Stories on environmental projects initiated by Christians have been collected from all over the world. These include stories from within the South African ${ }^{42}$ and Southern African ${ }^{43}$ contexts, from elsewhere in Africa, from the USA, and from elsewhere in the world. ${ }^{44}$

These local efforts are indeed vital. However, they will remain limited in their scale and effectiveness unless they are broadened to address the policy-making processes of govern-

39. See especially Bouma-Prediger (1998, 2000), Nash (1991:64-67) and Van Wensveen (1999, 2000) on the emergence of an ecological virtue ethics. Nash lists nine ecological virtues, i.e. sustainability, adaptability, relationality, frugality, equity, solidarity, biodiversity, sufficiency and humility. Nash (1995) argues that frugality constitutes economic subversion. He identifies four characteristics of such subversion:

1. Frugality rejects the popular assumption that humans are insatiable creatures, ceaselessly acquisitive for economic gains and goods and egoistically committed to pleasure maximization.

2. Frugality resists the temptations of consumerism and the ubiquitous pressures of advertising.

3. Frugality struggles against the various psychological and sociological dynamics that stimulate overconsumption.

4. Ethically conscious frugality rejects the prevailing ideology of indiscriminate, material economic growth.

40. The distinction between a vision for the good society, virtuous persons and responsible decision-making, based on appropriate values and obligations, describe three important moral quests. In an introductory course on Ethics at the University of the Western Cape the relationship between these three quests is used as a point of departure to structure the course. See also the "moral map" suggested by Birch \& Rasmussen (1989:35-65).

41. See Chapter 6 of Conradie \& Field (2000).

42. See Cock (1994), Conradie \& Field (2000:110).

43. See Conradie \& Field (2000:113f) and especially Daneel $(1999,2000)$ on the work of ZIRRCON.

44. See Niles (1989:32-35), Rajotte \& Breuilly (1992: 98-118). 
ments and business (including trans-national companies). To be effective at this level, churches have to join with other activist groups, to use the media or to engage in direct political activity. The united effort of individuals, local community organisations, nongovernment organisations, business corporations, governments, and international organisations is necessary to address global environmental threats adequately. In this sense, it is not only necessary to act locally, but also to act globally. ${ }^{45}$

This also implies the need for networking between Christians engaged in earthkeeping activities. In South Africa the recent establishment of a Network of Earthkeeping Christian Communities in South Africa (NECCSA) is certainly an appropriate step towards such a network. Together with well-established movements elsewhere in Africa, such as the Association of African Earthkeeping Churches (Zimbabwe) and the Kenya Greenbelt Movement, this may provide the backbone for a much wider initiative that may help to raise an environmental awareness not only in South Africa but also on the whole African continent. ${ }^{46}$

\section{REFERENCES}

Baker-Fletcher, K 1998. Sisters of dust. Womanist wordings on God and creation. Minneapolis: Fortress Press.

Béguin-Austin, M (ed.) 1993. Sustainable growth - contradiction in terms?, 69-88. Geneva: The Ecumenical Institute.

Berry, T 1988. The dream of the earth. San Francisco: Sierra Club Books.

Birch, BC \& Rasmussen, LL 1989. Bible \& Ethics in the Christian Life. Minneapolis: Augsburg Press.

Boff, L 1995. Ecology and liberation. Maryknoll: Orbis Books.

Bouma-Prediger, S 1998. Creation care and character: The nature and necessity of the ecological virtues. Perspectives on Science and Christian Faith 50, 6-21.

Bouma-Prediger, S 2000. Response to Louke van Wensveen: A constructive proposal. In: Hessel, DT \& Ruether, RR (eds.) 2000. Christianity and ecology. Seeking the wellbeing of earth and humans,173-181. Cambridge: Harvard University Press.

Cobb, JB (jr.) 1992. Sustainability. Economics, ecology and justice. New York: Orbis Books.

Cock, J \& Koch, E (eds.) 1991. Going green. People, politics and the environment in South Africa. Cape Town: Oxford University Press.

Cock, J 1992. Towards the greening of the church in South Africa: Some problems and possibilities. Missionalia 20:3, 174-185.

Cock, J 1994. Christian witness and ecology. International Review of Mission 83:328, 89-92.

Conradie, EM \& Field, DN 2000. A rainbow over the land. A South African guide on the church and environmental justice. Cape Town: Western Cape Provincial Council of Churches.

Conradie, EM 1997. Om met eenvoud te lewe (Prediker 3:9-15). In: Burger, CW, Müller, BA \& Smit, DJ (eds.) 1997. Riglyne vir prediking oor die Christelike deugde. Woord teen die Lig III/4, 174-183. Kaapstad: Lux Verbi.

Conradie, EM 2000. Hope for the earth - Vistas on a new century. Bellville: University of

45. See Béguin-Austin (1993:26f) also Mische (2000:599f) on the need for churches to act globally.

46. See Daneel's vision for such an African Earthkeepers' Union (Daneel 1999:320f). 
the Western Cape.

Conradie, EM 2001. Ecological theology: A guide for further research. Study Guides in Religion and Theology 5. Bellville: University of the Western Cape.

Conradie, EM 2002. Die ekologiese gevolge van 'n verbruikersmentaliteit. Kruisgewys 1:3, 36-39.

Daneel, ML 1998. African Earthkeepers. Volume 1. Interfaith mission in earth-care. African Initiatives in Christian mission 2. Pretoria: Unisa.

Daneel, ML 1999. African Earthkeepers. Volume 2. Environmental mission and liberation in Christian perspective. African Initiatives in Christian mission 3. Pretoria: Unisa.

Daneel, ML 2000. Earthkeeping churches at the African grass roots. In: Hessel, DT \& Ruether, RR (eds.) 2000. Christianity and ecology. Seeking the well-being of earth and humans, 531-552. Cambridge: Harvard University Press.

Durning, A 1990. Apartheid's environmental toll. Worldwatch Paper 95.

Fuggle, RF \& Rabie, MA 1992. Environmental management in South Africa. Cape Town: Juta.

Gudynas, E 1995. Ecology from the viewpoint of the poor. In: Boff, L \& Elizondo, V (eds.) 1995. Ecology and poverty. Cry of the earth, cry of the poor. Concilium 1995/5, 106-114. London: SCM Press.

Gunton, C 1993. The One, the Three and the Many: God, creation and the culture of modernity. Cambridge: Cambridge University Press.

Gustafson, JM 1994. A sense of the divine. The natural environment from a theocentric perspective. Edinburgh: T \& T Clark.

Hessel, DT (ed.) 1985. For creation's sake. Preaching, ecology, \& justice. Philadelphia: The Geneva Press.

Huntley, B, Siegfried, R \& Hunter, S 1989. South African environments into the 21st century. Cape Town: Human \& Rousseau \& Tafelberg.

Keller, C 1993. Talk about the weather: The greening of eschatology. In: Adams, C 1993. Ecofeminism and the sacred, 30-49. Maryknoll: Orbis Books.

Lawson, L 1991. The ghetto and the greenbelt. In: Cock, J \& Koch, E (eds.): Going green. People, politics and the environment in South Africa, 46-63. Cape Town: Oxford University Press.

McFague, S 1993. The body of God. An ecological theology. London: SCM Press.

McFague, S 2001. Life abundant. Rethinking theology and economy for a planet in peril. Minneapolis: Fortress Press.

Mische, PM 2000. The integrity of creation: Challenges and opportunities for praxis. In: Hessel, DT \& Ruether, RR (eds.) 2000. Christianity and ecology. Seeking the wellbeing of earth and humans, 591-602. Cambridge: Harvard University Press.

Moltmann, J 1989. Creating a just future: the politics of peace and the ethics of creation in a threatened world. London: SCM Press.

Müller-Fahrenholz, G 1995. God's Spirit transforming a world in crisis. New York: Continuum.

Nash, JA 1991. Loving nature: Ecological integrity and Christian responsibility. Abingdon Press.

Nash, JA 1995. Toward the revival and reform of the subversive virtue: Frugality. The Annual of the Society of Christian Ethics 1995, 137-160.

Niles, D Preman (ed.) 1989. Resisting the threats to life: Covenanting for justice, peace and the integrity of creation. Geneva: WCC Publications. 
Niles, D Preman (ed.) 1992. Between the flood and the rainbow. Geneva: World Council of Churches.

Raiser, K 1997. To be the church. Challenges and hopes for a new millennium. Geneva: World Council of Churches.

Rajendra, C 1987. Dove on fire: Poems on peace, justice and ecology. Geneva: World Council of Churches.

Rajotte, F \& Breuilly, E 1992. Treatment for the earth's sickness - The church's role. In: Breuilly, E \& Palmer, M (eds.) 1992. Christianity and ecology, 98-118. London: Cassell.

Ramphele, M \& McDowell, C (eds.) 1991. Restoring the land: Environment and change in post-apartheid South Africa. London: Panos.

Rasmussen, LL 1994. Theology of life and ecumenical ethics. In: Hallman, DG (ed.) 1994. Ecotheology. Voices from South and North, 112-129. Geneva: World Council of Churches.

Rasmussen, LL 1996. Earth community, earth ethics. Maryknoll: Orbis Books.

Roberts, E \& Amidon, E 1991. Earth prayers rom around the world. San Francisco: Harper \& Row.

Ruether, RR 1992. Gaia \& God: An ecofeminist theology of earth healing. Harper \& Collins Publishers.

Santmire, HP 1989. The future of the cosmos and the renewal of the church's life with nature. In: Peters, T (ed.): Cosmos as creation. Theology and science in consonance, 265-282. Nashville: Abingdon Press.

Scharper, SB \& Cunningham, H 1993. The green Bible. Maryknoll: Orbis Books.

Schumacher, EF 1973. Small is beautiful; Economics as if people mattered. San Francisco: Harper \& Row.

Schut, M 1999. Simpler living, compassionate life: A Christian perspective. Denver: The Morehouse Group.

Swimme, B 1996. The hidden heart of the cosmos. Humanity and the new story. Maryknoll: Orbis Books.

Tucker, ME \& Grim, J 2000. Series foreword. In: Hessel, DT \& Ruether, RR (eds.) 2000. Christianity and ecology. Seeking the well-being of earth and humans, 113-125. Cambridge: Harvard University Press.

Van Wensveen, L 1999. Dirty virtues: The emergence of ecological virtue ethics. Humanity Books.

Van Wensveen, L 2000. Christian ecological virtue ethics: Transforming a tradition. In: Hessel, DT \& Ruether, RR (eds.) 2000. Christianity and ecology. Seeking the wellbeing of earth and humans, 155-172. Cambridge: Harvard University Press.

Wadell, PJ 1994. Taming an unruly family member: Ethics and the ecological crisis. In: Fragomeni, RN \& Pawlikowski, JT (eds.) 1994. The ecological challenge. Ethical, liturgical, and spiritual responses. Collegeville: The Liturgical Press.

Ware, KT 1997. Through the creation to the creator. Ecotheology 2, 8-30.

White, L 1967. The historical roots of our ecological crisis. Science 155, 1203-7.

Whyte, AV (ed.) 1995. Building a new South Africa. Volume 4. Environment, reconstruction and development. Johannesburg: International Development Research Centre.

Yeld, J 1997. Caring for the earth. A guide to sustainable living. Stellenbosch: WWF South Africa. 